\title{
Additional Genes Controlling Flowering Time in Lactuca sativa and L. serriola
}

\author{
Edward J. Ryder ${ }^{1}$ and David C. Milligan ${ }^{2}$ \\ U.S. Department of Agriculture, Agricultural Research Service, 1636 East Alisal Street, Salinas \\ CA 93905
}

\begin{abstract}
AdDiTIONAL INDEX WORDS. L. sativa, L. serriola, lettuce, early flowering, bolting
Abstract. Six genes controlling flowering time or bolting time in Lactuca $\mathrm{L}$. have been reported. Several crosses between parents differing in time to opening of first flower were made to ascertain the inheritance of additional flowering time traits in Lactuca species. The parents in the crosses were of five flowering classes: very late (VL), late (L), early (E), very early (VE), and very, very early (VVE). Segregation from a cross between C-2-1-1 (VL) (L. sativa L.) and 'Vanguard 75' $(\mathrm{L})$ confirmed that 'Vanguard 75' flowering was controlled by the previously identified gene $E f-2 e f-2$. Mutant line 87-41M-7 (VVE) was crossed by D-3-22M (VE) and segregated 3VVE:1 VE, indicating a dominant allele, $E f-3$, that decreased flowering time an additional 7 days. Cos-like line 796 (VE) was crossed to cultivars Salinas (VL) and Vanguard 75. Segregation indicated a gene $E f-4 e f-4$, with lateness dominant. PI 175735 (E) (L. serriola L.), crossed with C-2-1-1 produced an $F_{2}$ population with a bimodal distribution, segregating $3 \mathrm{E}: 1 \mathrm{VL}$, indicating a single gene Ef-5ef-5. PI 236396 (E) and PI 250020 (E) were crossed to 'Salinas' and 'Vanguard 75'. Segregation and morphological similarity indicated the same gene in both PI lines, Ef-6ef-6, with earliness dominant.
\end{abstract}

Flowering time is closely associated with stem elongation in rosette forming plants such as lettuce (Lactuca sativa). Early stem elongation, or premature bolting, is a problem in lettuce production, since it can cause loss of quality or of the crop itself. Information about flowering time, and by extension, stem elongation, may be of use in breeding programs for bolting resistance.

Flowering time is an interesting trait in plants for other reasons. A sufficient degree of earliness enables a researcher to study the genetics and physiology of life cycles in short time periods (Ryder, 1996; Waycott, 1995; Waycott and Taiz, 1991; Waycott et al., 1991, 1995). Very early flowering plants are also useful as educational tools, as the rapid cycling enables the completion of a research project in short time periods (Hawk and Crowder, 1978). Earliness can be useful as a breeding tool, particularly in speeding up the backcross method (Ryder, 1985).

The earliest work on the genetics of earliness characteristics in Lactuca species was by Bremer (1931). He crossed a long-day cultivar ('Kaiser Treib') with a day-neutral cultivar ('Rudolph's Liebling'), and showed that long-day-influenced bolting was dominant and day-neutral was recessive. Bremer and Grana (1935) named the gene $T t$.

Early flowering time was identified by Ryder (1983) as a single gene trait. Later, a second gene was discovered (Ryder, 1988). The genes were named $E f-1 e f-1$ and $E f-2 e f-2$. Ef- $I$ is partially dominant to ef-1, while $E f-2$ is partially dominant to $e f-2$ when $E f-1$ is present, but recessive in the ef-1ef- 1 genotype. Plants that are homozygous dominant for both genes (very early, VE) flower under summer greenhouse conditions in $45 \mathrm{~d}$, while the double recessive flowers in $140 \mathrm{~d}$ (very late, VL). The trait is quantitatively photoperiod related; all genotypes are slower to flower in winter than summer. In another study, two quantitative analysis methods were used to identify three partially dominant genes

Received for publication 4 Nov. 2004. Accepted for publication 19 Nov. 2004 We thank B. Robinson and J. Tanaka for technical assistance. We acknowledge the California Lettuce Research Board for support of the research.

Research plant geneticist (retired) and collaborator. Corresponding author; e-mail: eryder@pw.ars.usda.gov

${ }^{2}$ Agricultural research technician. for flowering time (Kim and Ryder, 1994). This paper describes the continued work with early flowering in lettuce and its relatives. Specifically, we discuss early flowering traits inherited as qualitative characters.

\section{Materials and Methods}

From the previous flowering time studies, we were able to identify lines with the ef-1ef-1ef-2ef-2(VL) genotype, which could be used as a VL flowering parent in crosses to identify additional flowering time genes (Table 1). One of these lines, 81-1252-C-21-1 (C-2-1-1) (Ryder, 1996) was crossed with 'Vanguard 75' (L). 'Vanguard 75' is a crisphead lettuce grown in the late winter-early spring period in the California and Arizona desert districts. It flowers earlier than other current crisphead lettuces and was postulated to have $E f-2$ in its genotype (Ryder, 1988).

The cross with C-2-1-1 was made in 1986 . The $\mathrm{F}_{1}$ population was grown in the greenhouse in 1987. The $\mathrm{F}_{2}$ population was grown in 1988 and 1990 and $F_{3}$ families were grown in 1990. One segregating $\mathrm{F}_{3}$ family and parents were also grown in 1995.

Table 1. Seasonal flowering time ranges for early and late flowering parents used in crosses. Number of days from seeding to first open flower.

\begin{tabular}{lccl}
\hline Item & $\begin{array}{c}\text { Spring-summer } \\
(\mathrm{d})\end{array}$ & $\begin{array}{c}\text { Fall-winter } \\
(\mathrm{d})\end{array}$ & \multicolumn{1}{c}{$\begin{array}{c}\text { Flower } \\
\text { time class }\end{array}$} \\
\hline PI 175735 & $52-80$ & $128-166$ & Early \\
PI 236396 & $45-60$ & $82-124$ & Early \\
PI 250020 & $47-63$ & $97-116$ & Early \\
81-1252-C-2-1-1 & & & \\
$\quad$ (C-2-1-1) & $111-156$ & $192-214$ & Very late \\
Salinas & $125-150$ & $175-210$ & Very late \\
Vanguard 75 & $94-136$ & $163-178$ & Late \\
87-41M-7 & $36-42$ & NA & Very, very early \\
D-3-22M & $45-50$ & $65-69$ & Very early \\
09-960796-0 (796) & $45-49$ & NA & Very early \\
\hline
\end{tabular}

${ }^{\mathrm{z} F a l l-w i n t e r}$ plantings were not made. 
Line $87-41 \mathrm{M}$ is an early flowering line (Ef-1Ef-1Ef-2Ef-2, VE) (Table 1) that also carries the gene enen for endivelike leaf. A single plant (87-41M-7) in a small population flowered several days earlier (52 d, VVE) than the other plants (mean: $66 \mathrm{~d}$ ). The plant was crossed to D-3-22M, which is also Ef-1Ef-1Ef-2Ef-2 (VE). The VVE plant was lost and the population was regrown. Another VVE flowering plant was identified, assumed to be genetically the same as the original, and the cross was made again. $F_{1}$ populations were grown in 1995 from the original cross and in 1998 and 1999 from the second cross. One $\mathrm{F}_{2}$ population was grown from the first $F_{1}$ and two from the second. One group of $\mathrm{F}_{3}$ families was grown from the first $\mathrm{F}_{2}$ population and one from the second.

A group of lines was received from A. van der Arend, Leen de Mos Seed Co. (Gravenzande, The Netherlands) with various genetic anomalies. Among them was a cos line, 09-960796-0 (796), which flowered early; compared to a line D-3$22 \mathrm{M}(E f-1 E f-1 E f-2 E f-2)$, it flowered in about the same number of days (D-3-22M $=55.8 \mathrm{~d} ; 796=55.3$ d when seeded 29 Mar. 2002) (Table 1). Line 796 was crossed with 'Vanguard 75' and 'Salinas' (VL). $\mathrm{F}_{2}$ populations were grown in 2000, seeded 14 July 2000, and $F_{3}$ families in 2001, seeded 23 Mar. 2001 ('Vanguard 75' cross) and 20 Apr. 2001 ('Salinas' cross). A second seeding of $\mathrm{F}_{3}$ families from the 'Salinas' cross was made 22 May 2003.

Three Plant Introduction (PI) accessions were identified in greenhouse and growth chamber tests as early flowering. PI 175735 (L. serriola) (early, E) has elongated leaves with entire margins, spines on stems and leaf midribs (abaxial), anthocyanin, and it bolts and flowers early in a long-day environment and later in a short-day environment, but not as late as parents designated $\mathrm{L}$ or VL (Table 1). It was crossed with C-2-1-1, to produce $\mathrm{F}_{1}, \mathrm{~F}_{2}$, and $\mathrm{F}_{3}$ family populations. To investigate flowering time variation within the early class of the $\mathrm{F}_{2}$, two crosses were made between pairs of derived $\mathrm{F}_{4}$ lines from the original cross: I-B-20-2 (68 d) X I-A-5-2 (62 d) and I-B-20-4 (71 d) x I-A-5-3 (56 d). In each cross, the female parent was slightly later than the male parent. Parental, $F_{1}$, and $F_{2}$ populations from both crosses were seeded without replication 6 Mar. 1992. The same generations and $F_{3}$ families for the first cross only were seeded in two replications 2 Apr. 1993.

PI 236396 (L. sativa) (E) is a primitive oilseed type with elongated leaves, no spines, and anthocyanin on leaf margins (tinge). It flowers early during long days and later during short days (Table 1). PI 250020 (L. sativa) (E) is also an oilseed type, very similar in appearance and flowering time to PI 236396 (Table 1). PI 236396 and 250020 were each crossed with 'Salinas' and 'Vanguard 75', to produce $\mathrm{F}_{1}, \mathrm{~F}_{2}$, and $\mathrm{F}_{3}$ families.

Seed was sowed in a sand-soil mixture and transplanted at the three- to four-leaf stage to small plastic pots $\left(\sim 75 \mathrm{~cm}^{3}\right)$, one plant per pot. All plantings were grown in the greenhouse. Flowering time was measured as the number of days from seeding to first open flower. Flowering times for winter and summer conditions in the greenhouse are shown for all parents used in these studies (Table 1).

Flowering time varies over seasons within a year due primarily to changes related to photoperiod. From year to year, materials planted around the same planting date vary in flowering time due to temperature, greenhouse location, and other environmental differences (Ryder, 1996). Plants flower earliest when planted in the period from early March to early July; they flower latest when planted in the period late August to early December. Therefore, populations reported in this paper are identified by planting date. Genetic analysis was done by $\chi^{2}$ for one or two gene segregation data.

\section{Results}

\section{'Vanguard 75' x C-2-1-1}

The parents and $F_{1}$ populations were seeded 2 Oct. 1987. Six plants of 'Vanguard 75' and five of C-2-1-1 averaged 169.5 and $200.8 \mathrm{~d}$, respectively. There were only two $\mathrm{F}_{1}$ plants, flowering in 176 and $197 \mathrm{~d}$ (mean $186.5 \mathrm{~d}$ ), respectively. Therefore $\mathrm{F}_{1}$ flowering time appeared to be intermediate between the parents. An $\mathrm{F}_{2}$ population planted 24 June 1988 showed a bimodal distribution, with the preponderance of plants in the very late (VL) class (Fig. 1, Table 2). If the $\mathrm{F}_{2}$ distribution is divided at the low point, the proportion of VL:late (L) is approximately 3:1. A second seeding was made 18 May 1990. The $\mathrm{F}_{2}$ distribution was bimodal; flowering times approximated 3 VL:1 L (Fig. 1, Table 2).

The flowering times for the parents in the first experiment were outside the range of the $\mathrm{F}_{2}$ population component means. The plants were located several feet away from the $\mathrm{F}_{2}$, on another bench. In a small greenhouse, temperature and other conditions may vary from bench to bench, which may account for the difference. The relationships between the parents and the $\mathrm{F}_{2}$ were closer to expectation in the second planting. A segregating $F_{3}$ family, in lieu of a third $F_{2}$ population, for which there was insufficient 
seed, was grown in 1995, with random placement of the parents. This population segregated approximately: $3 \mathrm{VL}: 1$ $\mathrm{L}$, and the parental means coincided with the means of the VL and L classes, as expected (Table 2).

As there were only two $F_{1}$ plants grown in 1987 , an estimate for an $\mathrm{F}_{1}$ putatively grown along with the $1988 \mathrm{~F}_{2}$ population was made by obtaining the mean for $\mathrm{F}_{2}$ plants that produced segregating $\mathrm{F}_{3}$ families and were therefore heterozygous. The mean obtained was $143.5 \mathrm{~d}$, which is less than, but close to, the mean for the VL class of the $\mathrm{F}_{2}$ (150.5 d) and therefore supports the hypothesis that VL is dominant.

Among $\mathrm{F}_{3}$ families from $\mathrm{VL} \mathrm{F}_{2}$ plants of the 1988 planting, the ratio was approximately $1 \mathrm{VL}: 2$ segregating. Within segregating $\mathrm{F}_{3}$ families, the ratio $\mathrm{VL}: \mathrm{L}$ was again approximately $3: 1$. The conclusions are that a single gene controls the difference in flowering time and that VL is dominant to $\mathrm{L}$.

\section{7-41M-7 x D-3-22M}

Flowering time was recorded for the $\mathrm{F}_{1}$ population planted in 1999. There were two plants and both flowered in $48 \mathrm{~d}$, which was equivalent to the mean for VVE plants in the $\mathrm{F}_{2}$ population grown at the same time. This suggests that VVE flowering is dominant to $\mathrm{VE}$ flowering. All $\mathrm{F}_{2}$ populations segregated approximately $3 \mathrm{VVE}: 1 \mathrm{VE}$ (Table 3 ). Among $\mathrm{F}_{3}$ families, segregation approximated $1 \mathrm{VVE}: 2$ segregating:1 $\mathrm{VE}$ in both groups of families. Within segregating families, segregation approximated $3 \mathrm{VVE}: 1 \mathrm{VE}$ in both groups, as in the $\mathrm{F}_{2}$ (Table 3 ). The conclusion from these data is that a gene for flowering time has been identified and the earlier alIele is dominant to the later allele.

\section{Crosses}

$\mathrm{F}_{1}$ flowering times were estimated using the mean of $\mathrm{F}_{2}$ heterozygous plants, seeded 14 July 2000. The parental and $F_{1}$ flowering times were 'Salinas'= $142.6 \mathrm{~d}$; 'Vanguard $75^{\prime}=123.2 \mathrm{~d} ; 796=39 \mathrm{~d}$ (one plant); $796 \times$ 'Salinas' = $116.6 \mathrm{~d}$; and $796 \mathrm{x}$ 'Vanguard $75^{\prime}=111.7 \mathrm{~d}$; these indicate a high level of dominance for lateness ('Salinas' is VL and 'Vanguard 75' is L).

The 796 x 'Salinas' $F_{2}$ population, seeded 14 July 2000 , segregated 47 VL:26 E (Table 4), with clear separation between early and late values. However, 22 plants died before their flowering times were recorded; 15 of these were beginning to bolt and would have been late flowering plants. The others died too early to be identified. This would suggest segregation of $62 \mathrm{VL}: 26 \mathrm{E}$, not counting the seven unidentifiable plants $\left(\chi^{2}=0.97 ; P=0.30-0.50\right)$, giving a better 3:1 fit. Families of an $\mathrm{F}_{3}$ population seeded $20 \mathrm{Apr}$. 2001, segregated approximately 1 all VL: 2 segregating (Table 4). Within segregating families, segregation approximated 3 VL: 1 E. In a second $F_{3}$ population, planted 22 May 2003, from $\mathrm{VLF}_{2}$ plants only, segregation approximated 1 all VL:2 segregating among families, and $3 \mathrm{VL}: 1 \mathrm{E}$ within segregating families (Table 4). The evidence suggests a single gene, with lateness (VL) dominant.

The $796 \mathrm{x}$ 'Vanguard 75' $\mathrm{F}_{2}$ population, seeded 14 July 2000, segregated 55 L:27 E (Table 5). Of 14 plants that died unrecorded for flowering time, nine would have been late flowering and the rest were unknown. This suggests a 64 L:27
Table 2. Segregation for flowering time in the cross 'Vanguard 75' $x$ C-2-1-1. 'Vanguard 75' is late (L) and C-2-1-1 is very late (VL). Populations identified by date of planting.

\begin{tabular}{lrcrccc}
\hline Population & VL & $\begin{array}{c}\text { Mean } \\
(\mathrm{d})\end{array}$ & $\mathrm{L}$ & $\begin{array}{c}\text { Mean } \\
(\mathrm{d})\end{array}$ & $\chi^{2}$ & $P$ \\
\hline $\mathrm{F}_{2}$ (expect 3:1) & & & & & & \\
24 June 1988 & 179 & 150.5 & 53 & 111.8 & 0.57 & $0.30-0.50$ \\
18 May 1990 & 90 & 141.9 & 29 & 104.7 & 0.04 & $0.80-0.90$ \\
5 May 1995 & & & & & & \\
$\quad \quad$ Seg. F Family) & 84 & 133.8 & 36 & 113.3 & 1.60 & $0.20-0.30$ \\
Pooled & 353 & & 118 & & 0.006 & $0.90-0.95$ \\
F $_{3}$ families & & & & & & \\
$\quad$ (18 May 1990) & VL & Segregating & L & & & \\
Among (expect 1:2) & 16 & 25 & & & 0.60 & $0.30-0.50$ \\
Within (expect 3:1) & 228 & & 74 & & 0.04 & $0.80-0.90$ \\
\hline
\end{tabular}

Table 3. Segregation for flowering time in cross $87-41 \mathrm{M}-7 \times$ D-3-22M. Populations identified by date of planting. $87-41 \mathrm{M}-7$ is very, very early (VVE) and D-3-22M is very early (VE).

\begin{tabular}{lrccccc}
\hline Population & VE & $\begin{array}{c}\text { Mean } \\
(\mathrm{d})\end{array}$ & VE & $\begin{array}{c}\text { Mean } \\
(\mathrm{d})\end{array}$ & $\chi^{2}$ & $P$ \\
\hline F $_{2}$ (expect 3:1) & & & & & & \\
21 Feb. 1997 & 73 & 42.3 & 23 & 50.0 & 0.05 & $0.80-0.90$ \\
5 Feb. 1999 & 68 & 48.7 & 26 & 56.7 & 0.36 & $0.50-0.70$ \\
10 Mar. 2000 & 71 & 40.3 & 21 & 46.0 & 0.23 & $0.50-0.70$ \\
Pooled & 212 & & 70 & & 0.005 & $0.90-0.95$
\end{tabular}

$\mathrm{F}_{3}$ families

Among (expect 1:2:1) VVE Segregating VE

8 Aug. 1997

10 Mar. 2000

$\begin{array}{rrr}9 & 22 & \\ 9 & 16 & \\ 18 & 38 & 13\end{array}$

$\begin{array}{rrr}8 & 0.69 & 0.30-0.50 \\ 5 & 1.10 & 0.30-0.50 \\ 13 & 1.44 & 0.30-0.50\end{array}$

Within segregating families (expect 3:1)

$\begin{array}{llrrr}8 \text { Aug. } 1997 & 202 & 73 & 0.35 & 0.50-0.70 \\ \text { 10 Mar. } 2000 & 130 & 50 & 0.75 & 0.30-0.50 \\ \text { Pooled } & 332 & 123 & 1.00 & 0.30-0.50\end{array}$

Table 4. Segregation for flowering time in cross 09-9607796-0 (796) x 'Salinas.' 796 is very early (VE) and 'Salinas' is very late (VL). Populations identified by date of planting.

\begin{tabular}{|c|c|c|c|c|c|c|}
\hline Population & VL & $\begin{array}{c}\text { Range } \\
\text { (d) }\end{array}$ & $\mathrm{VE}$ & $\begin{array}{c}\text { Range } \\
\text { (d) }\end{array}$ & $\chi^{2}$ & $P$ \\
\hline \multicolumn{7}{|c|}{796 x 'Salinas' $F_{2}($ expect $3: 1)$} \\
\hline 14 July 2000 & 47 & $112-149$ & 26 & $44-54$ & 4.39 & $0.02-0.05$ \\
\hline $\mathrm{F}_{3}$ Families & VL & Segregating & & VE & & \\
\hline \multicolumn{7}{|c|}{ Among (expect 1:2) } \\
\hline 20 Apr. 2001 & 7 & 12 & & & 0.11 & $0.70-0.80$ \\
\hline 22 May 2003 & 5 & 14 & & & 0.42 & $0.50-0.70$ \\
\hline Pooled & 12 & 26 & & & 0.06 & $0.80-0.90$ \\
\hline \multicolumn{7}{|c|}{ Within (expect $3: 1$ ) } \\
\hline 20 Apr. 2001 & 98 & & & 37 & 0.41 & $0.50-0.70$ \\
\hline 22 May 2003 & 127 & & & 39 & 0.20 & $0.50-0.70$ \\
\hline Pooled & 225 & & & 76 & 0.012 & $0.90-0.95$ \\
\hline
\end{tabular}


Table 5. Segregation for flowering time in cross 09-960796-0 (796) $x$ 'Vanguard 75.' 796 is very early (VE) and 'Vanguard 75' is late (L). Populations identified by date of planting.

\begin{tabular}{|c|c|c|c|c|c|c|}
\hline Population & $\mathrm{L}$ & $\begin{array}{l}\text { Range } \\
\text { (d) }\end{array}$ & $\mathrm{VE}$ & $\begin{array}{l}\text { Range } \\
\text { (d) }\end{array}$ & $\chi^{2}$ & $P$ \\
\hline \multicolumn{7}{|c|}{$\begin{array}{l}796 \times x^{`} \text { Vanguard } 75^{\prime} \mathrm{F}_{2} \\
\text { (expect } 3: 1 \text { ) }\end{array}$} \\
\hline 14 July 2000 & 55 & $90-140$ & 27 & $43-57$ & 2.75 & $0.05-0.10$ \\
\hline $\begin{array}{l}\mathrm{F}_{3} \text { families } \\
(23 \text { Mar. 2001) }\end{array}$ & $\mathrm{L}$ & Segregating & $\mathrm{VE}$ & & & \\
\hline Among (expect 1:2) & 6 & 14 & & & 0.10 & $0.70-0.80$ \\
\hline Within (expect 3:1) & 126 & & 42 & & 0 & $>0.99$ \\
\hline
\end{tabular}

Table 6. Segregation for flowering time in the cross PI 175735 x C-2-11. PI 175735 is early (E) and C-2-1-1 is very late (VL). Populations identified by date of planting.

\begin{tabular}{|c|c|c|c|c|c|c|}
\hline Population & E & $\begin{array}{l}\text { Mean } \\
\text { (d) }\end{array}$ & VL & $\begin{array}{l}\text { Mean } \\
\text { (d) }\end{array}$ & $\chi^{2}$ & $P$ \\
\hline \multicolumn{7}{|c|}{$\begin{array}{l}175735 \times \mathrm{C}-2-1-1 \mathrm{~F}_{2} \\
\quad(\text { expect } 3: 1)\end{array}$} \\
\hline 24 June 1988 & 178 & 69.0 & 53 & 130.3 & 0.52 & $0.30-0.50$ \\
\hline 14 July 1989 & 85 & 76.2 & 33 & 143.3 & 0.56 & $0.30-0.50$ \\
\hline Pooled & 263 & & 86 & & 0.03 & $0.80-0.90$ \\
\hline $\begin{array}{l}\mathrm{F}_{3} \text { families } \\
14 \text { July } 1989\end{array}$ & $\mathrm{E}$ & Segregating & VL & & & \\
\hline $\begin{array}{l}\text { Among } \\
\quad(\text { expect } 1: 2: 1)\end{array}$ & 20 & 44 & 15 & & 1.65 & $0.30-0.50$ \\
\hline $\begin{array}{l}\text { Within } \\
\quad(\text { expect 3:1) }\end{array}$ & 371 & & 142 & & 1.96 & $0.10-0.20$ \\
\hline
\end{tabular}

E ratio $\left(\chi^{2}=1.05 ; P=0.30-0.50\right)$. An $\mathrm{F}_{3}$ population, seeded 23 Mar. 2001, segregated approximately 1 all L:2 segregating among families and $3 \mathrm{~L}: 1 \mathrm{E}$ within segregating families (Table 5). The evidence suggests a single gene, with lateness dominant.

\section{Crosses with PI accessions}

PI 175735. The $F_{1}$ of $175735 \times$ C-2-1-1 (VL) flowered in $151.8 \mathrm{~d}$, compared to $148.5 \mathrm{~d}$ for the early parent in a 2 Oct. 1987 seeding. The mean of heterozygous $\mathrm{F}_{2}$ plants grown in lieu of $F_{1}$ plants, seeded 24 June 1988, flowered in $69.7 \mathrm{~d}$, compared to $67.3 \mathrm{~d}$ for the early parent. Strong dominance for earliness is suggested. Two $\mathrm{F}_{2}$ populations were grown, seeded 24 June 1988 and 14 July 1989, respectively. Distributions were bimodal with a slight overlap. Divided at appropriate low points, they each segregated approximately $3 \mathrm{E}: 1 \mathrm{VL}$. Seventy-nine $\mathrm{F}_{3}$ families were seeded 14 July 1989. They segregated approximately 1 all E:2 segregating: 1 all VL. Within segregating families, segregation was approximately $3 \mathrm{E}: 1 \mathrm{VL}$, as expected. The evidence indicates a single gene, with earliness dominant (Table 6).

Variation within early and late classes in the distribution of $\mathrm{F}_{2}$ plants suggested additional genetic variation for earliness. Crosses between earlier and later plants in the early class were analyzed for further variation. In the non-replicated test, planted 6 Mar. 1992, a continuous distribution skewed towards the early side occurred in the $F_{2}$ for both crosses and the $F_{1} s$ were very close to the early parents, suggesting a quantitative basis, with earliness dominant. Similar distributions of the $F_{2}$ and among $F_{3}$ families were shown in the replicated experiment, seeded 2 April 1993. Regression of $F_{3}$ means on $F_{2}$ values was a straight line with slope $b=0.48$, also suggesting a quantitative genetic basis for the variation (Fig. 2). The nature of the genetic basis was not investigated further.

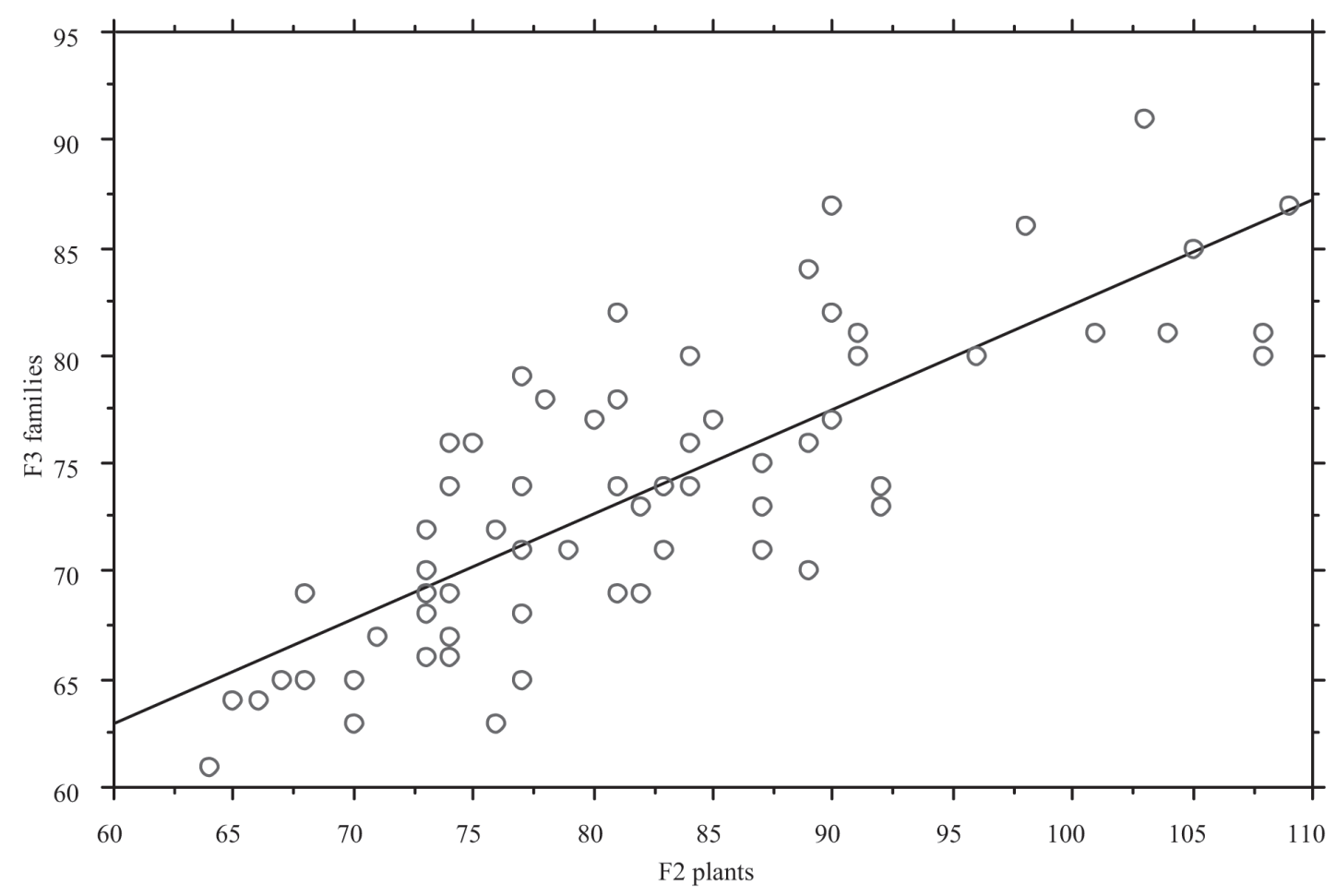

Fig. 2. Joint distribution of flowering times for $\mathrm{F}_{2}$ plants and $\mathrm{F}_{3}$ family means of PI $175735(\mathrm{E}) \mathrm{X} \mathrm{C}-2-1-1(\mathrm{VL})$. Regression equation: $\mathrm{Y}=34.17+0.48 \mathrm{X}$; $\mathrm{F}=119.81$; $P=<0.0001$ (E, early; VL, very late). 
PI 236396. The flowering time range for 10 plantings over 1 year for PI 236396 in the greenhouse is 45-124 d. Parental, $\mathrm{F}_{1}$, and $\mathrm{F}_{2}$ populations of crosses with 'Vanguard 75' and 'Salinas' were planted 26 May 2000. Parental means were PI $236396=53.3$ d, 'Salinas' $=140.2 \mathrm{~d}$, and 'Vanguard 75' $=120.4$ d. The $F_{1}$ with 'Vanguard 75 ' flowered in 62.3 d, and with 'Salinas' at $69.5 \mathrm{~d}$. The $\mathrm{F}_{2}$ distribution of 236396 x 'Vanguard 75' was divided into four distinct groups: a large early group and three later groups. The ratio of early to the sum of the later groups approximated 3:1 (Table 7). The $\mathrm{F}_{2}$ of 236396 $x$ 'Salinas' also was divided into four groups and the ratio of early to the sum of the late groups was also 3:1 (Table 7). If the numbers for the three late groups are summed for both crosses, the totals are 27:12:8. This approximates 9 early-late: 4 mid-late: 3 late-late $\left(\chi^{2}=0.09 ; P=0.95-0.98\right)$, suggesting two additional genes, exhibiting recessive epistasis, segregating within the late class. In the early class, it is difficult to distinguish among the subclasses, suggesting a much stronger effect of the primary gene. $\mathrm{F}_{3}$ families of $236396 \mathrm{x}$ 'Vanguard 75' segregated approximately 1 all E:2 segregating: 1 all L, and approximately $3 \mathrm{E}: 1 \mathrm{~L}$ within segregating families. $\mathrm{F}_{3}$ families from early $F_{2}$ plants of 236396 x 'Salinas' segregated approximately 1 all E:2 segregating and approximately $3 \mathrm{E}: 1 \mathrm{~L}$ within segregating families (Table 7).

PI 250020. The flowering time range for 10 plantings over 1 year for PI 250020 was $47-116 \mathrm{~d}$. Parental and $\mathrm{F}_{2}$ populations of crosses with 'Vanguard 75' and 'Salinas' were seeded 2 June 2000. The parental means were PI $250020=55.5 \mathrm{~d}$, 'Vanguard 75 ' $=111.0 \mathrm{~d}$, and 'Salinas' $=130.4 \mathrm{~d}$. Estimated $\mathrm{F}_{1}$ means from heterozygous $\mathrm{F}_{2}$ plants are $63.2 \mathrm{~d}$ for the cross with 'Vanguard 75 ' and $63.9 \mathrm{~d}$ for the cross with 'Salinas.' The $\mathrm{F}_{2}$ distributions of both 250020 x 'Vanguard 75' and 250020 x 'Salinas' were each divided into one large early group and three late groups. Each segregated approximately 3:1, early to sum of late groups (Table 8 ). When the numbers for the late groups for both crosses are summed the ratio of 24 early-late:10 mid-late:4 late-late is approximately $9: 4: 3\left(\chi^{2}=1.72 ; P=0.30-0.50\right)$. As with the crosses with 236396 , the segregation was apparently masked in the early group. $\mathrm{F}_{3}$ families of both $250020 x$ 'Vanguard 75' and 250020x 'Salinas' segregated approximately 1 all E:2 segregating: 1 $\mathrm{L}$ among families and $3 \mathrm{E}: 1 \mathrm{~L}$ within segregating families (Table 8).

\section{Discussion}

Genes for flowering time were identified in six sources: a commercial cultivar, a mutant line, a breeding line, and three PI accessions (Table 9).

Several pieces of evidence show that the gene identified in 'Vanguard 75' is $E f-2 E f-2$. The original cross of $56679 x$ ' Vanguard 75' segregated for two genes (Ryder, 1988). It is most likely that a single mutation occurred in the 56679 parent, ef- $I>E f-1$,
Table 7. Segregation for flowering time in crosses 'Vanguard 75' x PI 236936 and 'Salinas' x PI 236396. 'Vanguard 75' is late (L), 'Salinas' is very late (VL), and PI 236396 is early (E). Populations identified by date of planting.

\begin{tabular}{lcccccc}
\hline Population & E & $\begin{array}{c}\text { Range } \\
(\mathrm{d})\end{array}$ & $\begin{array}{c}\text { L } \\
\text { or VL }\end{array}$ & $\begin{array}{c}\text { Range } \\
(\mathrm{d})\end{array}$ & $\chi^{2}$ & $P$ \\
\hline F $_{2}$ (expect 3:1) & & & & & & \\
26 May 2000 & & & & & & \\
'Vanguard 75' x 236396 & 65 & $51-72$ & 27 & $91-149$ & 0.93 & $0.30-0.50$ \\
'Salinas' x 236396 & 65 & $50-78$ & 20 & $86-151$ & 0.09 & $0.70-0.80$ \\
F $_{3}$ families & & & & & & \\
'Vanguard 75' x 236396 & & & & & & \\
$\quad$ (29 June 2001) & E & Segregating & L & & & \\
Among (expect 1:2:1) & 6 & 9 & 5 & & 0.30 & $0.80-0.90$ \\
Within (expect 3:1) & 83 & & 24 & & 0.37 & $0.50-0.70$ \\
'Salinas' x 236396 & & & & & & \\
$\quad$ (9 Feb. 2001) & E & Segregating & VL & & & \\
Among (expect 1:2) & 5 & 11 & & & 0.03 & $0.80-0.90$ \\
Within (expect 3:1) & 102 & & 30 & & 0.36 & $0.50-0.70$ \\
\hline
\end{tabular}

Table 8. Segregation for flowering time in crosses 'Vanguard 75' x PI 250020 and 'Salinas' x PI 250020. 'Vanguard 75' is late (L), 'Salinas' is very late (VL), and PI 250020 is early (E). Populations identified by date of planting.

\begin{tabular}{lrcrrrr}
\hline Population & E & $\begin{array}{c}\text { Range } \\
(\mathrm{d})\end{array}$ & $\begin{array}{c}\text { L } \\
\text { or VL }\end{array}$ & $\begin{array}{c}\text { Range } \\
(\mathrm{d})\end{array}$ & \multicolumn{1}{c}{$\chi^{2}$} & \multicolumn{1}{c}{$P$} \\
\hline F $_{2}$ (expect 3:1) & & & & & & \\
$\quad$ 2 June 2000 & & & & & & \\
'Vanguard 75' x 250020 & 75 & $53-74$ & 21 & $91-153$ & 0.51 & $0.30-0.50$ \\
'Salinas' x 250020 & 73 & $51-100$ & 17 & $106-155$ & 1.79 & $0.10-0.20$ \\
F families & & & & & & \\
'Vanguard 75' x 250020 & & & & & & \\
(3 Sept. 2001) & $\mathrm{E}$ & Segregating & $\mathrm{L}$ & & & \\
Among (expect 1:2:1) & 8 & 11 & 5 & & 1.02 & $0.50-0.70$ \\
Within (expect 3:1) & 95 & & 37 & & 0.64 & $0.50-0.70$ \\
'Salinas' x 250020 & & & & & & \\
$\quad$ (6 July 2001) & $\mathrm{E}$ & Segregating & $\mathrm{VL}$ & & & \\
Among (expect 1:2:1) & 5 & 12 & 6 & & 0.13 & $0.90-0.95$ \\
Within (expect 3:1) & 95 & & 26 & & 0.80 & $0.30-0.50$ \\
\hline
\end{tabular}

Table 9. Characteristics of lettuce flowering time genes.

\begin{tabular}{lllc}
\hline Symbol & \multicolumn{1}{c}{ Source } & Dominance & Effect in days $^{z}$ \\
\hline Ef-2ef-2 & 'Vanguard 75' & Lateness & 34 \\
$E f-3 e f-3$ & $87-41 \mathrm{M}-7$ & Earliness & 7 \\
$E f-4 e f-4$ & $7966^{x}$ & Lateness & 78 \\
$E f-5 e f-5$ & PI 175735 & Earliness & 70 \\
$E f-6 e f-6$ & PI 236396 & Earliness & 50 \\
$E f-6 e f-6$ & PI 250020 & Earliness & 64
\end{tabular}

${ }^{\mathrm{z}}$ Reduction in time to first flower compared to late group in $\mathrm{F}_{2}$ population. $87-41 \mathrm{M}-7$ was crossed to D-3-22M, which is Ef-1Ef-1Ef-2Ef-2, very early, limiting further reduction by $E f-3$.

yIn absence of $E f-1$ (Ryder 1988). Previous work showed that the effect of $E f-1$ is $75-80$ d (Ryder 1983, 1988)

×Cos-like line 09-960796-0, received from A. van der Arend, Leen de Mos Seed Co., Gravenzande, The Netherlands. 
which gives the more drastic earliness effect, and that $E f-2$, which gives the more mild effect, already existed in 'Vanguard 75.' Lines developed from the cross, identified as ef-1ef-1Ef-2Ef-2, flower in the same time range as 'Vanguard 75.'

87-41M-7 is homozygous for the trait endive-like leaf, which provided the opportunity for a linkage study with the newly identified early flowering-3 (Table 9 ). The $\mathrm{F}_{2}$ populations, seeded 27 Feb. 1997 and 10 Mar. 2000, segregated for both traits, fitting the ratio $9 \mathrm{VVE}$, normal leaf:3 VVE, endive:3 VE, normal: $1 \mathrm{VE}$, endive $\left(\chi^{2}=1.10 ; P=0.70-0.80\right)$, and indicating independent inheritance.

Mean flowering times for the VVE and VE portions of the three $\mathrm{F}_{2}$ distributions of the cross $87-41 \mathrm{M}-7 \times \mathrm{D}-3-22 \mathrm{M}$ differed by 6,9 , and $6 \mathrm{~d}$, respectively. The approximate reduction of flowering time for each gene, sequentially from $E f-1$ alone, to $E f-1$ plus $E f-2$, to $E f-1$ plus $E f-2$ plus $E f-3$ is: $E f-1=140$ to 65 d; $E f-2=65$ to $45 \mathrm{~d}$; and $E f-3=45$ to $38 \mathrm{~d}$, when grown in the greenhouse during the summer. The effect of $E f-3$ in the absence of $E f-1$ and $E f-2$ is not known.

A group of $13 \mathrm{~F}_{4}$ lines from the cross, selected from plants of relatively short stature were seeded 29 Mar. 2002, and were read for flowering time and height. They ranged from $42.3-43.9 \mathrm{~d}$ and from $8.5-19.6 \mathrm{~cm}$. This compares to $51.2 \mathrm{~d} / 37.8 \mathrm{~cm}$ for $81-41 \mathrm{M}-7$ and $55.8 \mathrm{~d} / 38.0 \mathrm{~cm}$ for D-3-22M, suggesting that selecting for shorter plants also selects for increased earliness.

The $\mathrm{F}_{2}$ distributions of the crosses $796 \mathrm{x}$ 'Vanguard 75 ' and $796 \times$ 'Salinas' differ in the late classes. In the latter $\mathrm{F}_{2}$, the late class ranges from 112-149 d, while in the former, the late class ranges from 76-140 d. The difference may be the effect of $E f-2$ from 'Vanguard 75 '.

For the $796 \mathrm{x}$ 'Salinas' cross, the mean of seven $\mathrm{F}_{2}$ plants homozygous for lateness was $133.3 \mathrm{~d}$ and for 26 early plants was $48.6 \mathrm{~d}$, a difference of about $85 \mathrm{~d}$. The mean of homozygous late $\mathrm{F}_{3}$ families of the $796 \mathrm{x}$ 'Salinas' cross is $124.8 \mathrm{~d}$, while the mean of early plants in the segregating families is $49.1 \mathrm{~d}$, a difference of $76 \mathrm{~d}$. For the $796 \mathrm{x}$ 'Vanguard 75 ' cross, flowering dates for late $\mathrm{F}_{3}$ plants were not recorded. Flowering dates for $\mathrm{F}_{2}$ plants only were used to compare. The mean of six plants homozygous for lateness was $121.8 \mathrm{~d}$, and for 27 early plants was $49.7 \mathrm{~d}$, a difference of $72 \mathrm{~d}$. Therefore, the average reduction in flowering time controlled by the gene is about $78 \mathrm{~d}$.

PI accessions 236396 and 250020 are very similar in appearance as well as flowering time. PI 250020 was received from Egypt and is a typical oilseed type from that area. PI 236396 was received from Japan, but may have been originally collected from Egypt. The similarity in the $\mathrm{F}_{2}$ distributions of the crosses with 'Salinas' and 'Vanguard 75 ' strongly suggest that the primary flowering time gene is the same for each.

The apparent 9 early-late:4 mid-late:3 late-late ratios in all four $F_{2}$ populations suggests another pair of genes in both PI lines, whose effects are noticeable only in the late group. It also suggests that the effect of $E f-2 e f-2$, which should show in the 'Vanguard 75' crosses, is effectively masked.
Only one allelism test was performed to establish relationships among the genes discussed in this paper or with Ef-lef-1 and Ef$2 e f-2$. $E f-3$ co-segregated with $E f-1$ and $E f-2$ and therefore must be different from either. Evidence strongly suggests they are all different genes, except for the indication that $E f-6$ is in both P236396 and PI 250020 (Table 9). The recessive earliness allele ef-4 reduces flowering time by more than twice as many days as $e f-2$, and is therefore most likely different. Among the dominant early alleles, $E f-5$ has a similar effect to $E f-1$ and a slightly lesser effect than $E f-6$, but the pattern of segregation of $E f-5 e f-5$ is less discrete, showing an overlapping bimodal distribution in $\mathrm{F}_{2}$, while the other two separate discretely. It is also substantially later than either $E f-1$ or $E f-6$ under short days (Table 1) (Ryder, 1983)). Ef-6 and $E f-1$ have similar effects, but their origins are different: $E f-6$ occurs in a primitive oilseed lettuce, while $E f-1$ mutated recently in a crisphead breeding line (Ryder, 1988).

The full effect of $E f-3$ is not known in the absence of $E f-1$ and $E f-2$. It is possible that $E f-3$ and $E f-6$ have the same magnitude of effect. However, the sources of the two genes are different, suggesting that they are not the same.

No linkage or marker tests were performed, so the location of the genes on the chromosomes is not known. Further work with these genes might therefore include mapping and allelism studies. The earliest alleles may be useful in educational applications and plant development studies.

\section{Literature Cited}

Bremer, A.H. 1931. Effect of day length on bolting in lettuce (in German). Genetische Untersuchungen I. Gartenbauwissenschaft 4:469-483.

Bremer A.H. and J. Grana. 1935. Genetic research with lettuce (in German). II. Gartenbauwissenschaft 9:231-245.

Hawk, J.A. and L.V. Crowder. 1978. Brassica campestris L., a higher plant with potential for teaching genetics. J. Hered. 69:121-124.

Kim,Z.H. and E.J. Ryder. 1994. Inheritance of days to flowering in lettuce (Lactuca sativa L.) (in Korean). Korean J. Breeding 25:291-301.

Ryder, E.J. 1983. Inheritance, linkage, and gene interaction studies in lettuce. J. Amer. Soc. Hort. Sci. 108:985-991.

Ryder, E.J. 1985. Use of early flowering genes to reduce generation time in backcrossing, with specific application to lettuce breeding. J. Amer. Soc. Hort. Sci. 110:570-573.

Ryder, E.J. 1988. Early flowering time in lettuce as influenced by a second flowering time gene and seasonal variation. J. Amer. Soc. Hort. Sci. 113:456-460.

Ryder, E.J. 1996. Ten lettuce genetic stocks with early flowering genes Ef-1ef-1 and Ef-2ef-2. HortScience 31:473-475.

Waycott, W. 1995. Photoperiodic response of genetically diverse lettuce accessions. J. Amer. Soc. Hort. Sci. 120:460-467.

Waycott, W., S.B. Fort, and E.J. Ryder. 1995. Inheritance of dwarfing genes in Lactuca sativa L. J. Hered. 86:39-44.

Waycott, W., V.A. Smith, P. Gaskin, J. MacMillan, and L. Taiz. 1991. The endogenous gibberellins of dwarf mutants of lettuce. Plant Physiol. 95:1169-1173.

Waycott, W. and L. Taiz. 1991. Phenotypic characterization of lettuce dwarf mutants and their response to applied gibberellins. Plant Physiol. 95:1162-1168. 